\title{
EDUCATION ON PUBLIC FINANCE MANAGEMENT: THE CASE OF PUBLIC EXPENDITURE AND PROCUREMENT
}

\author{
Prof. Dr. Gediminas Dubauskas \\ The General Jonas Žemaitis Military Academy of Lithuania
}

\begin{abstract}
Public finance, spending transparency and taxation revenue collection policy is an important issue for every country. Therefore, general education in these fields is very important, especially in the post-communist societies. As these social science disciplines influence the development of a country and citizens, many countries make the use of civic education and public understanding of financial study as a way to justify citizens' responsibility. This paper raises and examines such cases and the subject of this scientific problem - public financial management as an important element of national education. Moreover, paid taxes and their spending create a clear microclimate in the society. Nevertheless, the real tax burden should be distributed equally. Obvious legal proceedings of the tax payment diversion in the public create additional tensions. The study also discusses financial education in Bachelor's and Master's degree study programs of social sciences for cadets (and students). The topics of public finance expenditure and procurement are becoming increasingly important in the 21st century. Proper social control of public procurement allows a public system to meet its needs in achieving important goals. The problem in many institutions is that procurement specialists carry out public acquisition with some problems that prevent from smooth execution of public sector expenditure management. Meanwhile, due to constant tension in the society caused by mismanaging expenditure (and therefore raising tax burden), prevailing non-transparent use of public finance and national budget deficit, public finance conceptualization is becoming crucial. Furthermore, it creates a direct benefit to the overall development of cadets and students' education.
\end{abstract}

Keywords: education, public finance management, expenditure, procurement, transparency

\section{Introduction}

Finance and public money management have a historical concept of educational process and is one of the key economic and financial preparation in contemporary education.

Money subject is possible with a number of complex aspects, both permanent change in the market economy and historical origin of money and monetary politics. 
Why such knowledge is necessary for the first grade university education? Financial education is relevant to each university undergraduate program. Incidentally, budget terminology and personal income taxation are known only from employment relationships or labor relations or comparable to labor relations income.

The purpose of the paper is to reveal the importance of financial management to cadets and students, including public perception of administration and financial aspects of public revenues' mismanagement related to tax burden.

The object of the research is the financial (and partially economic) perception of the cadets of The General Jonas Žemaitis Military Academy of Lithuania and other students of higher education institutions of public finance and mismanagement of public expenditure and procurement in addition to the taxation burden concept.

The objectives of the paper are as follows: to review financial and public finance development in the contemporary scientific literature; to display a necessity for cadets and students' education of public finance and public expenditure management. One of the key tasks of the paper is to reveal how taxation and public spending are perceived by the citizens. In addition, it also attempts to answer the questions about the financial and economic importance of financial education. Moreover, the applied task of the paper is to reveal the size of public procurement and expenditure in Lithuania and other European Union countries.

The research methods and methodology used in the research were formal analysis and qualitative and quantitative research methods; the data was taken from Lithuanian and other EU financial institutions. A separation of full-time and parttime students and cadets were made for informal surveys. It is also necessary to mention the data of teaching public finance management, articles and educational textbooks collected by the author for many years. The data for this paper were taken from the Lithuanian Department of Statistics, Public Procurement Office, European Statistical Agency, State Tax Inspectorate and Transparency International (Lithuanian division).

A well-functioning public sector that delivers quality public services consistent with citizen preferences and fosters private market-led growth while managing fiscal resources prudently is considered critical to the mission of poverty alleviation and the achievement of each post-totalitarian country's development goals (Brammer, S., Walker, H., 2007). This important new series aims to advance those objectives by disseminating conceptual guidance and lessons from practices and by facilitating learning from mutual experiences on the ideas and practices that promote responsive (by matching public services with citizens' preferences), responsible (through efficiency and equity in service provision without undue fiscal and social risk) and accountable (to citizens for all actions) public governance in the developing countries (Shah, A. (ed.), 2013). 


\section{Mismanagement of Public Expenditure}

There are many cases when central and municipal governments and their institutions misconduct public money. Likewise, there can be a possible anticipation of corruption. Reportable by local financial experts, corruption 'take in' about 11 per cent of Lithuania's GDP, and in the monetary expression it is more than EUR 4 billion. It is an enormous sum of money, even if this criterion is based on the experts' insights. The amount of what could be used for public good is probably taken by the corrupt Lithuanian institutions, such as the Ministry of Health, Ministry of Agriculture, etc. Corruption thrives in the well-known sectors, i.e. public construction and municipalities. For instance, Vilnius Municipality's water supply department has received permanent negative evaluations from the Public Procurement Office and other procurement institutions. The European Court of Justice proved a failure to fulfil the obligations of the following documents: Directive 2004/18/EC-Procedures for the award of public works contracts, public supply contracts and public service contracts - Contract for the supply, installation and maintenance of dispensing machines for hot drinks, and the supply of tea, coffee and other ingredients - Article 23(6) and 23(8) - Technical specifications - Article 26 - Conditions for performance of the contract - Article 53 - Criteria for award of the contracts - Most economically advantageous tender - Products derived from organic agriculture and fair trade Use of labels in the formulation of the technical specifications and the award criteria - Article 39 - Concept of 'additional information' - Article 2 - Principles for award of contracts - Principle of transparency - Articles 44 and 48 - Verification of the suitability and choice of participants - Minimum level of technical or professional abilities - Compliance with 'criteria of sustainability of purchases and socially responsible business' (OJ 2004 L 134, p. 114, and corrigendum OJ 2004 L351, p.44), as amended by Commission Regulation (EC) No 1422/2007 of 4 December 2007 (OJ 2007 L 317, p. 34) ('Directive 2004/18').

Nevertheless, financial mismanagement is management that, intentionally or not, is handled in a way that can be characterized as 'incorrect, uneconomical or unqualified' and that will indicate negatively upon the financial standing of a public institution or an individual. There are many ways to carry out financial mismanagement. For example, wrong distribution of responsibility, neglecting payments, bills and taxes and declining responsibility. Financial problems and economical standing can cause great financial mismanagement and further impact country's economics. Looking to various cases where financial management was wrong, it is possible to comprehend the outcome financial mismanagement can have and how critical it is for an economy's success to carry out well-working financial management and especially public finance spending and procurement. 


\section{Importance of Public Procurement}

Proper enforcement of public acquisition allows public system to meet its needs in achieving strategic objectives. The problem in many institutions is that procurement specialists carry out public acquisition featured with various problems that impede smooth execution of public sector procurement. The problems are individual, specific or systemic, the appearance of which depend not only on the complexity of the object of procurement and specialist competence but also on the legislation. The theoretical part of procurement as the main mode of acquisition, the concept and principles of its volumes, the essence of public finances and analyzed public procurement legal regulations highlight the efficiency of public procurement and the factors influencing the value of procurement management (Tvaronavičiene, A., 2017).

It can be argued that the basic principles of public procurement are honesty, transparency, elimination of corruption, equality of rights, rationality and efficient use of taxpayers' money. These principles are similarly laid down in the Law on Public Procurement of the Republic of Lithuania (2017). The Article 3 states that the contracting authority must ensure that the principles of equality, nondiscrimination, mutual recognition, proportionality and transparency are observed in the procurement procedures and determine the winner. Procurement management is essential to ensure the identification of goods, need for services and access to and management of external resources. Proper procurement allows meeting the needs and strategic goals of an organization (The Definitions of Procurement and Supply Chain Management, 2013). Well-managed purchases give a company added value, allow efficient use of tangible and human resources and reduce time costs (Procurement Management, 2017).

In the European Union, procurement accounted for about 16 per cent of total domestic product in 2015 (Eurostat Yearbook, 2016, Lastauskaite, G., Rudauskiene, $R$., 2015). However, public procurement accounted for 11.2 per cent of Lithuania's GDP in 2015. Therefore, this segment has a huge impact on the entire state economy (Statistics of Lithuania, Public Procurement Office, 2016). The main financial costs of the state are the maintenance of the bureaucratic apparatus (government, ministries and institutions that are associated with them), education, medical protection, social benefits, police, military maintenance and infrastructure investments. Therefore, it can be said that the funds provided in the state budget are used to perform state functions. Nevertheless, the transparency of public procurement is very low (Transparency International Lithuania, Research Report, 2016). 


\section{Conclusions}

The clarity of public spending and procurement and budgetary policy are essential issues for every country. According to financial experts, corruption 'consumes' about 11 per cent of Lithuania's GDP, i.e. more than EUR 4 billion. The amount of what could be used for public good is taken by the corrupt Lithuanian institutions, such as health care system, the Seimas (Lithuanian Parliament), municipalities, etc. Moreover, the most corrupt Lithuanian ministries are those of health, national defence and agriculture. In addition, it flourishes in the most corrupt sectors, i.e. pharmacy, construction and other public organizations.

Therefore, an integrated financial literacy is essential for cadets and students' education. Moreover, the sooner the students get it, the better the results will be. Recently published Public Financial Education Plan provides guidance on how the Ministry of Education and Science will include financial and tax literacy in formal education programs and will enable teachers to improve and maintain qualifications in financial and tax literacy. It is a really good initiative. It might be worth considering what actions should be taken further so that the plan is justified by a document. Because of serious changes, the orders of the Minister of Education are not enough, active involvement of universities, lecturers and businesses is necessary.

\section{References}

1. Allen, R. and Tommasi, D (eds.) (2011) Managing Government Expenditure: A Reference Book for Transition Countries. Paris: OECD. SIGMA. [Access on the Internet]: www1.worldbank.org/ publicsector/pe/oecdpemhandbook.pdf

2. Brammer, S.; Walker, H. 2007. Sustainable Procurement Practise in the Public Sector: an International Comparative Study. [Access on the Internet] http:// www.bath.ac.uk/management/ research/pdf/2007-16.pdf

3. Cambridge Dictionary. (2017). [Access on the Internet]: http://dictionary. cambridge.org/dictionary/english/public-procurement

4. European Court of Justice, (OJ 2004 L 134, p.114, and corrigendum OJ 2004 L 351, p. 44), as amended by Commission Regulation (EC) No 1422/2007 of 4 December 2007 (OJ 2007 L 317, p. 34) ('Directive 2004/18')." [Access on the Internet]: http://ec.europa.eu/justice/policies/privacy/docs/c_524_06/ ecj_judg huber_c_524_06_en.pdf

5. Eurostat Yearbook, (2016). [Access on the Internet]: http://ec.europa.eu/ eurostat/publications/statistical-books/eurostat-yearbook

6. Lastauskaitè, G., Rudauskienè, R. (2015). Viešuju pirkimu skaidrumas kaip įstatymu leideja saistantis principas. Teisè, Nr. 96, ISNN 1392-1274. [Transparency of Public Procurement as a Binding Principle for the Legislator. The Law, No 96, ISNN 1392-1274.]

7. Lietuvos Respublikos Seimo 1996 m. rugpjūčio 13 d. Lietuvos Respubli- 
kos viešųų pirkimų ịstatymas Nr. I-1491 (1996). Valstybès žinios (Nr. 84-2000), (galiojanti suvestinè redakcija nuo 2017-01-01). [Law on Public Procurement of the Republic of Lithuania: Seimas of the Republic of Lithuania, 1996 August 13 Law No. I-1491 (1996). State Gazette (No. 84-2000), (valid consolidated version as of 01.01.2017)].

8. Ministry of Finance of Lithuania (2017). [Access on the Internet]: http:// finmin.lrv.lt/lt/aktualus-valstybes-finansu-duomenys/valstybes-biudzeto-ir-savivaldybiu-biudzetu-vykdymo-duomenys.

9. Procurement Management (2017). [Access on the Internet]: https://www. deltabid.com/procurement-management/

10. Schiavo-Campo, S. and Tommasi, D. (1999) Managing Government Expenditure. Manila: ADB. [Access on the Internet]: www.adb.org/documents/ manuals/govt_expenditure/

11. Shah, A. (ed.) (2013) Budgeting and Budgetary Institutions. Washington, DC: World Bank. [Access on the Internet]: http://siteresources.worldbank.org/PSGLP/Resources/BudgetingandBudgetaryInstitutions.pdf

12. Transparency International, Lithuanian Division. (2017). [Access on the Internet]: http://www.transparency.lt/en/tilc-research-and-analysis/

13. Tvaronavičienè, A., (2012). Viešieji pirkimai kaip vienas iš darniojo vystymosi koncepcijos igyvendinimo instrumentu [Possibilities to Use Public Procurement as One of the Instruments of Sustainable Development in the Republic of Lithuania], Verslas: teorija ir praktika [Business: Theory and Practice] 13(3), p. 197-207. 


\title{
VIEŠŲJŲ FINANSŲ VADYBOS MOKYMAS: VALSTYBĖS IŠLAIDOS IR VIEŠIEJI PIRKIMAI
}

\author{
Prof. dr. Gediminas Dubauskas
}

\author{
Generolo Jono Žemaičio Lietuvos karo akademija
}

\section{Santrauka}

Viešieji finansai ir pinigu politikos samprata yra svarbi ir universali kiekvienos šalies bendruomenès ugdymo sritis. Šios socialiniu mokslu disciplinos daro itaka šalies raidai ir atskiru piliečiu gyvenimui, todèl dangelyje valstybiu piliečiu ugdymui pasitelkiamos ir viešuju finansu suvokimo studijos kaip būdas pagristi pilietiškuma. Straipsnyje iškeliamos ir nagrinèjamos temos bei mokslinès problemos - viešuju finansu valdymo, kaip svarbios pilietiškumo ugdymo studiju dalies, reikšmingumas - dirbančiuju sumokamu mokesčiu dydis ir reali mokestinè našta. Taip pat aptariamas studentu kariūnu finansinis ugdymas socialiniu mokslu krypties programose. Dvidešimt pirmojo amžiaus pradžioje mokesčiu ir viešuju finansu tematika tampa vis labiau aktuali dèl nuolatinès pastoviu ìtampu visuomeneje didinant mokesčius (ir mokestinę našta) dèl dažnu valstybiniu biudžetu deficitu ir viešuju finansu suvokimo tiesioginès naudos bendram pilietiškumo ugdymo plètojimui.

Tinkamas viešuju pirkimu vykdymas leidžia valstybinei sistemai patenkinti savo poreikius, siekiant strateginiu tikslu. Daugelio instituciju problema yra ta, kad pirkimo specialistai, vykdantys viešaji pirkima, susiduria su ịvairiomis problemomis, trukdančiomis sklandžiai vykdyti viešojo sektoriaus viešuosius pirkimus, o dažnai tokios problemos dirbtinai sukuriamos, siekiant asmeninès naudos.

Kaip teigia finansu ekspertai, korupcija ,,suvartoja “ apie 11 procentu Lietuvos bendrojo vidaus produkto, o jei šis skaičius mažai pasako, tuomet pinigine išraiška būtu daugiau nei 4 milijardai euru. Tai yra milžiniški pinigai, net jei šis matavimas labiau pagrịstas ekspertinèmis įžvalgomis. Didžiausia dali to, kas galètu būti panaudota visuomeniniam gèriui, galimai pasiima veikëjai korumpuočiausiose Lietuvos institucijose - sveikatos priežiüros sistemoje, Seime, savivaldybèse. Dar galima pridèti ir Lietuvos Respublikos ministerijas - sveikatos apsaugos, žemès ükio ir daugeli kitu. Panašu, kad tokie neskaidrūs sandoriai galimai nusèda korumpuočiausiuose sektoriuose - farmacijos, statybu ir įvairiose techninès patikros imonèse.

Todèl integruotas finansinio raštingumo ugdymas yra bütinas. Neišvengiamas ir viešuju finansu skaidrumo suvokimas. Kuo anksčiau studentai ji gaus, tuo geresniu rezultatu pasieksime. Gana naujai paskelbtame visuomenès finansinio švietimo plane numatytos gairès, kaip Švietimo ir mokslo ministerija ịtrauks finansini ir mokesčiu raštinguma i formaliojo ugdymo programas ir sudarys galimybes pedagogams tobulinti ir palaikyti kvalifikacija finansinio ir mokesčiu raštingumo srityje. Galimai vertètu svarstyti, kokiu veiksmu imtis toliau, kad planas nelikty 
tik popieriniame variante. Rimtiems pokyčiams vien tik ịsakymu turbūt neužtenka, bütinas ir universitetu programu papildymas, dèstytoju ir kariünu dalyvavimas ir tikrasis viešuju finansu kilmès suvokimas.

\section{AUTORIAUS LYDRAŠTIS}

Autoriaus vardas, pavardė: Gediminas Dubauskas

Mokslo laipsnis ir vardas: daktaras, profesorius

Darbo vieta ir pareigos: Generolo Jono Žemaičio Lietuvos karo akademija, Vadybos katedros profesorius

Autoriaus mokslinių interesų sritys: vadyba, finansai, ekonomika, edukologija

Telefonas ir el.pašto adresas: (8 6) 727 9858; gediminas.dubauskas@1ka.1t

\section{AUTHOR'S COVER LETTER}

Author's name and surname: Gediminas Dubauskas

Academic degree and name: Professor, Doctor

Workplace and position: The General Jonas Žemaitis Military Academy of Lithuania, Department of Management

Author's research interests: management, finance, economics, education

Telephone and e-mail address: +370672 79 858, gediminas.dubauskas@lka.lt 